\title{
Value of colposcopy in genitourinary departments
}

\author{
JANET D WILSON, * A SHIRLEY HILL, $†$ DAVID A HICKS* \\ From the *Department of Genitourinary Medicine, Royal Hallamshire Hospital, and $†$ Department of Pathology, \\ Jessop Hospital for Women, Sheffield
}

SUMMARY During 18 months 237 colposcopies were performed on 227 patients in the department of genitourinary medicine, Sheffield. Histological evidence of cervical intraepithelial neoplasia was found in 118 patients (52\%), of whom $104(88 \%)$ were aged under 35, $93(79 \%)$ under 30, and 64 $(54 \%)$ under 25 . Most were treated with local destructive treatment, only five (4\%) requiring cone biopsy.

Colposcopy in a genitourinary department has an important part to play in detecting cervical intraepithelial neoplasia, particularly in younger women. Early diagnosis may often facilitate using local destructive treatment, thereby reducing the numbers of patients needing cone biopsy.

The numbers of cervical cytology smears being reported as dyskaryotic are increasing, particularly in younger women.' Substantial evidence now links cervical intraepithelial neoplasia (CIN) and infection with human papilloma virus (HPV). ${ }^{23}$ Numbers of patients presenting to genitourinary clinics with HPV infections in recent years are also increasing rapidly, ${ }^{3}$ and the increase in our clinic in 1974 to 1984 was threefold. It is not surprising therefore that cervical cytology smears taken in genitourinary clinics show a high percentage of dyskaryosis. ${ }^{45}$ Only two thirds of women in the UK with an abnormal smear can be offered colposcopy, and it has been recommended that more centres should offer such a facility. ${ }^{6} \mathrm{~A}$ colposcopy service in genitourinary departments therefore seems to be a necessity.

We report the results of a colposcopy service in our clinic during 18 months.

\section{Patients and methods}

The data concern patients attending for colposcopy in January 1985 to June 1986. All patients had had a previous abnormal cervical cytology smear taken in our department. Our policy for cervical cytology screening is to perform yearly smears if women have past or present genital warts or genital herpes, or are known to have been sexual contacts of men with genital warts. Other patients undergo cervical

Address for reprints: Dr David A Hicks, Department of Genitourinary Medicine, Royal Hallamshire Hospital, Glossop Road, Sheffield S10 2JF

Accepted for publication 10 May 1987 cytology if it has not been performed elsewhere within the previous three years.

Colposcopy was arranged if cervical cytology showed moderate dyskaryosis or worse. If mild dyskaryosis was reported, repeat cytology at six months was arranged; if the result was again abnormal colposcopy was undertaken. If the cervix looked indicative of malignancy, despite normal cytology results, colposcopy was also arranged. (This accords closely with recently published guidelines for managing women with abnormal cervical cytology.?

At the time of colposcopy, a repeat cervical cytology smear and direct punch biopsy specimen were taken from any abnormal area. Patients with histologically confirmed CIN were referred to the local gynaecology colposcopy and laser clinic. Follow up after treatment was then continued there. A close working relation exists between our department and the colposcopy and laser clinic. One operator (DH) and a gynaecology consultant colleague operate that service. Both departments share the same cytology and histology service.

Patients with biopsy specimens suggesting wart virus infection were either treated with cryotherapy of the affected areas or were left untreated. All were followed up by us at six months with cytology or colposcopy, or both, and biopsy when indicated, and further follow up was undertaken when appropriate.

\section{Results}

In the 18 month period 237 colposcopies were performed on 227 patients. The mean age was 24.8 years (range 15-57). Table 1 shows age distribution against cervical biopsy findings. In patients who had two 
Table 1 Age distribution against cervical biopsy result

\begin{tabular}{|c|c|c|c|c|c|c|c|}
\hline \multirow[b]{2}{*}{ Age } & \multirow[b]{2}{*}{ No } & \multicolumn{6}{|c|}{ Cervical biopsy results } \\
\hline & & Normal & Inflammatory & Warty & CIN 1 & CIN 2 & CIN 3 \\
\hline $\begin{array}{l}15-19 \\
20-24 \\
25-29 \\
30-34 \\
35-39 \\
40-44 \\
\text { Over } 45\end{array}$ & $\begin{array}{r}41 \\
102 \\
42 \\
22 \\
7 \\
9 \\
4\end{array}$ & $\begin{array}{r}9 \\
15 \\
2 \\
4 \\
1 \\
4\end{array}$ & $\begin{array}{l}2 \\
5 \\
5\end{array}$ & $\begin{array}{r}22 \\
26 \\
6 \\
7\end{array}$ & $\begin{array}{l}4 \\
1 \\
1 \\
1\end{array}$ & $\begin{array}{r}4 \\
30 \\
13 \\
2 \\
2 \\
4 \\
2\end{array}$ & $\begin{array}{r}4 \\
22 \\
15 \\
8 \\
3 \\
1 \\
1\end{array}$ \\
\hline Total & 227 & 35 & 13 & 61 & 7 & 57 & 54 \\
\hline
\end{tabular}

$\mathrm{CIN}=$ cervical intraepithelial neoplasia

Table 2 Correlation of cytology results with biopsy findings

\begin{tabular}{|c|c|c|c|c|c|c|}
\hline \multirow[b]{2}{*}{ Cytology } & \multirow[b]{2}{*}{ No } & \multicolumn{5}{|l|}{ Histology } \\
\hline & & $\begin{array}{l}\text { Normal or } \\
\text { inflammatory }\end{array}$ & Warty & CIN I & CIN 2 & CIN 3 \\
\hline $\begin{array}{l}\text { Normal } \\
\text { Warty changes } \\
\text { Mild dyskaryosis } \\
\text { Moderate dyskaryosis } \\
\text { Severe dyskaryosis }\end{array}$ & $\begin{array}{r}4 \\
18 \\
40 \\
128 \\
37\end{array}$ & $\begin{array}{r}4 \\
5 \\
7 \\
28 \\
4\end{array}$ & $\begin{array}{l}11 \\
17 \\
33\end{array}$ & $\begin{array}{l}1 \\
5 \\
1\end{array}$ & $\begin{array}{r}1 \\
10 \\
42 \\
4\end{array}$ & $\begin{array}{r}1 \\
24 \\
29\end{array}$ \\
\hline Total & 227 & 48 & 61 & 7 & 57 & 54 \\
\hline
\end{tabular}

$\mathrm{CIN}=$ cervical intraepithelial neoplasia.

colposcopies performed, the worst histological diagnosis was used. Of 118 patients $(52 \%)$ with cervical biopsies showing CIN, 104 (88\%) were aged under 35, $93(79 \%)$ under 30 , and $64(54 \%)$ under 25.

Table 2 correlates cervical cytology results that initiated colposcopy with the cervical biopsy results in the 227 women. When a report was imprecise (for example, showing mild dyskaryosis with warty features) the worst grade was used. Compatible results were found in 91 cases $(\mathbf{4 0 \%})$, and acceptable correlation (within one grade) was present in 148 cases $(62 \%)$. Some discrepancy is inevitable because of the subjectivity of both histological and cytological gradings; especially at the mild end of the range and when features of wart virus infection are combined with
CIN. Some lesions regressed between the initiating smear and colposcopy.

Table 3 shows the treatments given to patients with abnormal biopsy findings. The patients with CIN were referred to the gynaecology colposcopy and laser clinic. Five required cone biopsy because the disease extended into the cervical canal. One patient underwent hysterectomy because of other unrelated gynaecological problems. Of the three patients with CIN who received no treatment, two had no evidence of disease on examination just before laser treatment (possibly because the lesion had been removed at biopsy or because the disease had regressed naturally) and one defaulted from all treatment appointments.

Patients with cervical biopsies showing wart virus

Table 3 Treatment regimens for 179 patients with abnormal biopsy findings

\begin{tabular}{|c|c|c|c|c|c|c|c|}
\hline \multirow{2}{*}{$\begin{array}{l}\text { Histology } \\
\text { finding }\end{array}$} & \multirow[b]{2}{*}{ No } & \multicolumn{6}{|c|}{ Treatment } \\
\hline & & None & Cryotherapy & Diathermy & Laser & Cone biopsy & Hysterectomy \\
\hline $\begin{array}{l}\text { Warty } \\
\text { CIN } 1 \\
\text { CIN } 2 \\
\text { CIN } 3\end{array}$ & $\begin{array}{r}61 \\
7 \\
57 \\
54\end{array}$ & $\begin{array}{r}13 \\
1 \\
2\end{array}$ & $\begin{array}{r}47 \\
4 \\
1\end{array}$ & 2 & $\begin{array}{r}1 \\
3 \\
52 \\
47\end{array}$ & $\begin{array}{l}1 \\
4\end{array}$ & 1 \\
\hline Total & 179 & 16 & 52 & 2 & 103 & 5 & 1 \\
\hline
\end{tabular}

$\mathrm{CIN}=$ cervical intraepithelial neoplasia 
infection were either treated with cryotherapy or observed. Six month follow up of 24 patients receiving cryotherapy gave negative results in 19 and persistent evidence of wart virus infection in five. Of six patients receiving no treatment, five gave negative results at six month follow up and one had persistent evidence of wart virus infection. The other 31 patients with initial biopsies showing wart virus infection were still awaiting their six month follow up at the time of writing.

\section{Discussion}

Our results show that we are identifying young women with a potentially progressive, yet treatable, serious disease. Over half the 118 with CIN were aged under 25 . The present DHSS cervical screening recomendations mean that these patients may not have had cervical cytology performed elsewhere for 10 or more years. Because these patients were diagnosed at an early age only five (4\%) (aged $24,31,32,34$, and 40 ) required cone biopsy. All others received local ablative treatment.

Singer $e t$ al also looked at a young population, but only $22 \%$ of their patients were aged under 25 . By contrast $11 \%$ of their patients needed cone biopsy. The substantial advantage to both patient and health service of early diagnosis requiring only local ablative treatment was described well. ${ }^{8}$

Biopsies showing CIN were found in 118 patients, who were referred to the gynaecology clinic. We are probably unique in our relation with this clinic in having one operator working in both departments, but other genitourinary departments could develop an arrangement with their gynaecological colleagues for referring patients with CIN. We follow up all other patients. In this respect we remove workload from the gynaecology clinic by filtering out patients with no cervical pathology and patients with wart virus infection. This allows the gynaecologists to reduce waiting lists and give more time to seeing general practitioner referrals and treating patients with CIN. The diagnosis of patients with cervical wart virus infection identifies a group at high risk of future development of premalignant disease. Regular follow up will therefore allow earlier detection of CIN.

A further advantage of performing colposcopies in our department is the continuity of care. This is especially beneficial for patients who may find colposcopy a frightening prospect. If laser treatment is needed, and referral elsewhere is necessary, our patients may be reassured to know that the referring doctor may continue to treat them.

Our present practice of following up patients with mild dyskaryosis at six months by repeat cytology probably now needs reviewing. Two papers have highlighted the poor correlation between mild dyskaryosis and CIN 1, with many patients having evidence of CIN 2 or $3 .{ }^{910}$ (Indeed, we too found poor correlation between mild dyskaryosis and histology findings). Campion et al also found that two consecutive negative cervical smears do not accurately predict regression of disease, which can only be confirmed accurately by colposcopy. ${ }^{10}$ It therefore seems that all patients with mild dyskaryosis should undergo colposcopy.

The recommendations made by the Board of Science and Education suggest that screening should start before the age of 35 and be repeated every three years or fewer. " Our results and those of Singer et al certainly support the need for screening patients before they are $35^{8}$

A study by Hicks and Bushell shows that several genitourinary doctors are either using a colposcope or are interested in training in colposcopy. ${ }^{12}$ From our experience we think this will be greatly beneficial in detecting and treating CIN, especially in younger women, and also will identify patients who are at high risk of future development of CIN.

\section{References}

1 Wolfendale MR, King S, Usherwood MM. Abnormal smears: are we in for an epidemic? Br Med J 1983;287:526-8.

2 McCance DJ, Campion MJ, Clarkson PK, Chesters PM, Jenkins D, Singer A. Prevalence of human papillomavirus type 16 DNA sequences in cervical intraepithelial neoplasia and invasive carcinoma of the cervix. Br J Obstet Gynaecol 1985;92:1101-5.

3 Anonymous. Genital warts, human papillomaviruses and cervical cancer. [Editorial] Lancet 1985;ii:1045-6.

4 Briggs RM, Holmes KK, Kiviat N, Barker E, Eschenbach DA, DeJong R. High prevalence of cervical dysplasia in STD clinic patients warrants routine cytologic screening. Am J Public Health 1980;70:1212-4.

5 Wilson JD, Woolley PD, Hicks DA, Kinghorn GR. Prevention of cervical cancer. Lancet 1986;ii:401.

6 Sharp F, Jordan JA. How many colposcopy centres do we need in the UK? In: Jordan JA, Sharp F, Singer A, eds. Preclinical neoplasia of the cervix. London: Royal College of Obstetricians and Gynaecologists, 1982:281-6.

7 BSCCP Working Party on Terminology in Gynaecological Pathology. Management of women with abnormal cervical smears. Bulletin of the Royal College of Pathologists. No 56, September 1986:1-2.

8 Singer A, Walker P, Tay SK, Dyson J. Impact of introduction of colposcopy to a district general hospital. Br Med J 1984; 289:1049-51.

9 Walker EM, Dodgson J, Duncan ID. Does mild atypia on a cervical smear warrant further investigation? Lancet 1986; ii:672-3.

10 Campion MJ, McCance DJ, Cuzick J, Singer A. Progressive potential of mild cervical atypia: prospective cytological, colposcopic, and virology study. Lancet 1986;ii:237-40.

11 Board of Science and Education. Cervical screening in Great Britain. London: BMA. Cited in Br Med J 1986;293:970.

12 Hicks DA, Bushell TEC. Colposcopy in genitourinary medicine clinics. Genitourin Med 1986;62:284. 